\title{
Rhodanobacter ginsengisoli sp. nov. and Rhodanobacter terrae sp. nov., isolated from soil cultivated with Korean ginseng
}

Hang-Yeon Weon, ${ }^{1}$ Byung-Yong Kim, ${ }^{2}$ Seung-Beom Hong,
Young-Ah Jeon, ${ }^{2}$ Soon-Wo Kwon, ${ }^{2}$ Seung-Joo Go ${ }^{2}$ and Bon-Sung Koo ${ }^{2}$

\author{
${ }^{1}$ Applied Microbiology Division, National Institute of Agricultural Science and Technology, Rural \\ Development Administration, Suwon 441-707, Republic of Korea \\ ${ }^{2}$ Korean Agricultural Culture Collection (KACC), Microbial Genetics Division, National Institute of \\ Agricultural Biotechnology, Rural Development Administration, Suwon 441-707, Republic of Korea
}

Two bacterial isolates from ginseng fields in Korea, strains GR17-7 ${ }^{\top}$ and GP18-1 ${ }^{\top}$, were characterized using a polyphasic approach. Phylogenetic analysis of their 16S rRNA gene sequences revealed a clear affiliation with the Gammaproteobacteria, and showed that the closest phylogenetic relationships were with members of the genus Rhodanobacter. The 16S rRNA gene sequence similarity between strains GR17-7 ${ }^{\top}$ and GP18-1 ${ }^{\top}$ was $97.2 \%$. Both strains showed 16S rRNA gene sequence similarities of $95.2-96.9 \%$ to type strains of recognized Rhodanobacter species. The $\mathrm{G}+\mathrm{C}$ contents of the DNA of strains GR1 7-7 ${ }^{\top}$ and GP18-1 ${ }^{\top}$ were 61.0 and $62.5 \mathrm{~mol} \%$, respectively. According to the DNA-DNA hydridization tests, the hybridization value between strains GR17- $7^{\top}$ and GP18- $1^{\top}$ was $34 \%$. Strains GR17-7 $7^{\top}$ and GP18-1 ${ }^{\top}$ showed less than $32 \%$ DNA-DNA relatedness with Rhodanobacter fulvus KCTC $12098^{\top}$ and Rhodanobacter spathiphylli LMG $23181^{\top}$. Strains GR17-7 ${ }^{\top}$ and GP18-1 ${ }^{\top}$ were aerobic, Gram-negative, rod-shaped, and catalase- and oxidase-positive. Major fatty acids of both strains were iso- $\mathrm{C}_{17: 1} \omega 9 \mathrm{c}$ and iso- $\mathrm{C}_{16: 0}$. Based on the data presented, two novel Rhodanobacter species are proposed, with the names Rhodanobacter ginsengisoli sp. nov. (type strain GR17-7 ${ }^{\top}=$ KACC $11762^{\top}=\mathrm{DSM} 18993^{\top}$ ) and Rhodanobacter terrae sp. nov. (type strain GP18-1 ${ }^{\top}=$ KACC $11761^{\top}=$ DSM $19241^{\top}$ ).
The genus Rhodanobacter was proposed for Gram-negative, aerobic, yellow-coloured bacteria isolated from soil. The major fatty acids are iso- $\mathrm{C}_{17: 1} \omega 9 c$, iso- $\mathrm{C}_{15: 0}$ and iso- $\mathrm{C}_{17: 0}$, and the DNA $\mathrm{G}+\mathrm{C}$ contents are in the range 63$67.8 \mathrm{~mol} \%$. Phylogenetically, these micro-organisms are related to the genera Dyella, Frateuria and Fulvimonas within the family Xanthomonadaceae. At the time of writing the genus comprised Rhodanobacter lindaniclasticus, Rhodanobacter fulvus and Rhodanobacter spathiphylli (Nalin et al., 1999; Im et al., 2004; De Clercq et al., 2006).

In the course of a study of bacterial diversity in fields cultivated with Korean ginseng (Panax ginseng C. A. Meyer), two bacterial strains, GR $17-7^{\mathrm{T}}$ and GP18-1 ${ }^{\mathrm{T}}$, were isolated in Yeongju and Ansung provinces, respectively, South Korea. Soil samples were suspended in sterilized water and diluted solutions were spread on R2A agar (Difco) and incubated at $28{ }^{\circ} \mathrm{C}$. Purified colonies were obtained from subcultures.

The GenBank/EMBL/DDBJ accession numbers for the 16S rRNA gene sequences of strains GR17-7 ${ }^{\top}$ and $\mathrm{GP} 18-1^{\top}$ are EF166075 and EF166076, respectively.
The isolates were tested for a number of key characteristics, such as Gram staining, catalase, oxidase and hydrolysis of casein, DNA, gelatin, starch and Tween 80 , by using standard procedures (Smibert \& Krieg, 1994). Growth was assessed at 5, 10, 20, 25, 30, 35 and $40{ }^{\circ} \mathrm{C}$, at $\mathrm{pH} 4,5,6,7$, 8,9 and 10 , and at $0,1,3,5$ and $7 \%(\mathrm{w} / \mathrm{v}) \mathrm{NaCl}$. Hydrolysis of carboxymethylcellulose $(0.1 \%$, w/v; Sigma), chitin from crab shells $(1 \%, \mathrm{w} / \mathrm{v})$, pectin $(0.5 \%, \mathrm{w} / \mathrm{v})$ and tyrosine $(0.5 \%$, w/v) was also determined. Cell morphology and motility were observed using light microscopy (AXIO; Zeiss) and transmission electron microscopy (model 912AB; LEO). In addition, the strains were characterized by using the whole test-spectrum of the API 20NE, API ID 32GN and API ZYM systems (bioMérieux), according to the manufacturer's instructions. The API ZYM test strip was read after $4 \mathrm{~h}$ incubation at $37{ }^{\circ} \mathrm{C}$ and the other API test strips were examined after 5 days at $28{ }^{\circ} \mathrm{C}$. The two strains were aerobic, Gramnegative, rod-shaped and catalase- and oxidase-positive. Strain GR17- $7^{\mathrm{T}}$ grew well on R2A medium and trypticase soy agar (TSA; Difco), grew weakly on nutrient agar (NA; Difco) and did not grow on MacConkey agar (Difco). 
Strain GP18-1 ${ }^{\mathrm{T}}$ grew well on R2A medium and weakly on NA, but did not grow on TSA or MacConkey agar. The phenotypic characteristics of strains GR $17-7^{\mathrm{T}}$ and GP18- $1^{\mathrm{T}}$ are summarized and compared with those of type strains of closely related taxa in Table 1 .

Fatty acid methyl esters were extracted and prepared from cells grown on R2A agar for $48 \mathrm{~h}$ at $28^{\circ} \mathrm{C}$ by using the standard protocol of the Microbial Identification System (MIDI; Microbial ID). The DNA G $+\mathrm{C}$ content was determined as described by Mesbah et al. (1989) using a reversed-phase column (Supelcosil LC-18 S; Supelco). Strains GR17-7 ${ }^{\mathrm{T}}$, GP18-1 ${ }^{\mathrm{T}}$, R. spathiphylli LMG $23181^{\mathrm{T}}$ and $R$. fulvus KCTC $12098^{\mathrm{T}}$ contained a variety of fatty acids, including iso- $\mathrm{C}_{16: 0}$, iso- $\mathrm{C}_{17: 1} \omega 9 c$, iso- $\mathrm{C}_{15: 0 \text {, iso- }}$ $\mathrm{C}_{11: 0} 3-\mathrm{OH}$, iso- $\mathrm{C}_{11: 0}$, anteiso- $\mathrm{C}_{15: 0}$, summed feature 3 (comprising iso- $\mathrm{C}_{15: 0}$ 2-OH and/or $\mathrm{C}_{16: 1} \omega 7 c$ ) and unknown 11.799 (Table 2). Strain GR17-7 ${ }^{\mathrm{T}}$ contained iso- $\mathrm{C}_{17: 1} \omega 9 c(16.2 \%)$, iso- $\mathrm{C}_{16: 0}(14.8 \%)$ and iso- $\mathrm{C}_{11: 0} 3$ $\mathrm{OH}(10.2 \%)$, and GP18- ${ }^{\mathrm{T}}$ contained iso- $\mathrm{C}_{17: 1} \omega 9 \mathrm{c}$ $(19.3 \%)$, iso- $\mathrm{C}_{16: 0}(19.1 \%)$ and iso- $\mathrm{C}_{15: 0}(10.4 \%)$ as the major fatty acids. The DNA $\mathrm{G}+\mathrm{C}$ contents of strains GR $17-7^{\mathrm{T}}$ and GP18- ${ }^{\mathrm{T}}$ were 61.0 and $62.5 \mathrm{~mol} \%$, respectively, which were slightly lower than those of other members of the genus Rhodanobacter.

The $16 \mathrm{~S}$ rRNA gene was amplified by PCR with primers fD1 and rP2 (Weisburg et al., 1991), and the entire PCR fragment was sequenced directly (Hiraishi, 1992). Multiple sequence alignments were performed using CLUSTAL w (Thompson et al., 1994). Phylogenetic trees were constructed by using the neighbour-joining method with the MEGA3 program package (Kumar et al., 2004). DNA-DNA hybridization was carried out as described by Seldin \& Dubnau (1985). Probe labelling was conducted by using the non-radioactive DIG High Prime DNA labelling and detection starter kit II (Roche Molecular Biochemicals). The hybridized DNA was visualized using the DIG luminescent detection kit (Roche). Phylogenetically, strains GR $17-7^{\mathrm{T}}$ and $\mathrm{GP} 18-1^{\mathrm{T}}$ were found to be closely related to members of the genus Rhodanobacter (Fig. 1). The 16S rRNA gene sequence similarity between strains GR $17-7^{\mathrm{T}}$ and GP18-1 ${ }^{\mathrm{T}}$ was $97.2 \%$. Both strains showed $95.2-96.9 \%$ sequence similarities with the type strains of the three recognized species of the genus Rhodanobacter. According to the DNA-DNA hybridization tests, the relatedness between strains GR $17-7^{\mathrm{T}}$ and $\mathrm{GP} 18-1^{\mathrm{T}}$ was $34 \%$. Strains $\mathrm{GR} 17-7^{\mathrm{T}}$ and GP18- $1^{\mathrm{T}}$ exhibited less than $32 \%$ DNA-DNA relatedness with R. fulvus KCTC $12098^{\mathrm{T}}$ and R. spathiphylli LMG $23181^{\mathrm{T}}$.

For R. spathiphylli LMG $23181^{\mathrm{T}}$, we obtained phenotypic results (for example, gelatin hydrolysis, assimilation patterns and enzymic reactions) that were slightly different from those reported by De Clercq et al. (2006). Also, the fatty acid compositions of $R$. fulvus KCTC $12098^{\mathrm{T}}$ and $R$. spathiphylli LMG $23181^{\mathrm{T}}$ determined in this study were also slightly different from those given by De Clercq et al. (2006). These discrepancies were supposed to be due to differences in the cultivation conditions used, such as media and incubation periods. Phenotypically, strains
Table 1. Differential phenotypic characteristics of strains GR17-7 ${ }^{\top}$ and GP $18-1^{\top}$ and type strains of Rhodanobacter species

Strains: 1, GR17- $7^{\mathrm{T}}$ (Rhodanobacter ginsengisoli sp. nov.; data from this study); 2, GP18-1 ${ }^{\mathrm{T}}$ (Rhodanobacter terrae sp. nov.; this study); 3 , R. lindaniclasticus LMG $18385^{\mathrm{T}}$ (Nalin et al., 1999); 4, R. fulvus KCTC $12098^{\mathrm{T}}\left(\mathrm{Im}\right.$ et al., 2004 and this study); 5, R. spathiphylli LMG $23181^{\mathrm{T}}$ (De Clercq et al., 2006 and this study). All strains are positive for catalase and oxidase. All strains are negative for nitrate reduction, glucose fermentation, indole production, arginine dihydrolase and urease. All strains assimilate D-glucose, but not L-arabinose, Dmannitol, potassium gluconate, phenylacetic acid, L-rhamnose, Dribose, inositol, sucrose, sodium malonate, potassium 5-ketogluconate, glycogen, D-sorbitol or potassium 2-ketogluconate. With the exception of R. lindaniclasticus LMG $18385^{\mathrm{T}}$, all strains assimilate 3hydroxybutyric acid, but not adipic acid, itaconic acid, suberic acid, L-alanine, 3-hydroxybenzoic acid, L-serine, propionic acid, L-histidine or 4-hydroxybenzoic acid (data not reported for $R$. lindaniclasticus LMG $18385^{\mathrm{T}}$ ). All strains except R. lindaniclasticus LMG $18385^{\mathrm{T}}$ show positive activities for alkaline phosphatase, esterase (C4), esterase lipase (C8), leucine arylamidase, acid phosphatase and naphthol-ASBI-phosphohydrolase, but are negative for lipase (C14), trypsin, $\alpha$ chymotrypsin, $\alpha$-mannosidase and $\alpha$-fucosidase (data not reported for R. lindaniclasticus LMG $18385^{\mathrm{T}}$ ). +, Positive; -, negative; ND, not determined.

\begin{tabular}{|c|c|c|c|c|c|}
\hline Characteristic & 1 & 2 & 3 & 4 & 5 \\
\hline Motility & + & - & - & + & - \\
\hline Aesculin hydrolysis & + & + & + & + & - \\
\hline Gelatin hydrolysis & + & - & ND & - & + \\
\hline \multicolumn{6}{|l|}{ Assimilation of: } \\
\hline D-Mannose & - & + & - & + & - \\
\hline $\mathrm{N}$-Acetylglucosamine & + & + & - & + & + \\
\hline Maltose & + & + & - & + & + \\
\hline Capric acid & - & - & + & - & - \\
\hline Malic acid & - & + & + & - & - \\
\hline Trisodium citrate & - & - & + & - & - \\
\hline Sodium acetate & + & - & $\mathrm{ND}$ & - & + \\
\hline Lactic acid & - & - & + & - & - \\
\hline Salicin & - & - & - & + & - \\
\hline D-Melibiose & - & - & - & + & - \\
\hline L-Fucose & - & + & - & - & - \\
\hline Valeric acid & + & - & $\mathrm{ND}$ & - & + \\
\hline L-Proline & + & + & $\mathrm{ND}$ & - & - \\
\hline \multicolumn{6}{|l|}{ Enzymic activities } \\
\hline Valine arylamidase & + & - & ND & + & + \\
\hline Cystine arylamidase & - & - & ND & - & + \\
\hline$\alpha$-Galactosidase & - & - & - & + & - \\
\hline$\beta$-Galactosidase & - & + & - & + & - \\
\hline$\beta$-Glucuronidase & - & - & ND & + & - \\
\hline$\alpha$-Glucosidase & + & - & ND & + & + \\
\hline$\beta$-Glucosidase & + & - & ND & + & - \\
\hline$N$-acetyl- $\beta$-glucosaminidase & + & - & ND & + & + \\
\hline DNA G $+C$ content $(\mathrm{mol} \%)$ & 61.0 & 62.5 & 63.0 & 65.3 & 67.6 \\
\hline
\end{tabular}

GR17-7 ${ }^{\mathrm{T}}$ and GP18-1 ${ }^{\mathrm{T}}$ differed from each other in properties such as motility, gelatin hydrolysis, assimilation patterns of several substrates and enzymic reactions. In 
Table 2. Cellular fatty acid compositions of strains GR17-7 and GP18-1 ${ }^{\top}$ and type strains of Rhodanobacter species

Strains: 1, GR17- ${ }^{\mathrm{T}}$ (Rhodanobacter ginsengisoli sp. nov.); 2, GP18-1 ${ }^{\mathrm{T}}$ (Rhodanobacter terrae sp. nov.); 3, R. fulvus KCTC $12098^{\mathrm{T}} ; 4, R$. spathiphylli LMG $23181^{\mathrm{T}}$. All data are from this study. All strains were grown for 2 days on R2A medium. Values are percentages of total fatty acids.,$-<0.5 \%$ or not detected; ECL, equivalent chain-length.

\begin{tabular}{|c|c|c|c|c|}
\hline Fatty acid & 1 & 2 & 3 & 4 \\
\hline iso- $\mathrm{C}_{11: 0}$ & 8.3 & 3.7 & 3.6 & 4.2 \\
\hline iso- $\mathrm{C}_{11: 0} 3-\mathrm{OH}$ & 10.2 & 5.6 & 5.3 & 6.0 \\
\hline iso- $\mathrm{C}_{12: 0} 3-\mathrm{OH}$ & 3.1 & 1.7 & 1.2 & 3.9 \\
\hline iso- $\mathrm{C}_{13: 0} 3-\mathrm{OH}$ & 5.5 & 2.6 & 2.6 & 2.1 \\
\hline $\mathrm{C}_{14: 0}$ & - & - & 0.9 & - \\
\hline iso- $\mathrm{C}_{14: 0}$ & 2.2 & 1.9 & 2.6 & 4.9 \\
\hline iso- $\mathrm{C}_{15: 0}$ & 7.3 & 10.4 & 16.2 & 8.3 \\
\hline iso- $\mathrm{C}_{15: 1} \mathrm{~F}$ & - & - & 0.8 & - \\
\hline anteiso- $\mathrm{C}_{15: 0}$ & 5.0 & 7.3 & 6.3 & 4.8 \\
\hline $\mathrm{C}_{16: 0}$ & 1.3 & 4.1 & 5.1 & 1.5 \\
\hline iso- $\mathrm{C}_{16: 0}$ & 14.8 & 19.1 & 13.2 & 28.4 \\
\hline iso- $\mathrm{C}_{16: 1} \mathrm{H}$ & 0.6 & - & - & 1.1 \\
\hline $\mathrm{C}_{17: 0}$ cyclo & - & - & 3.2 & - \\
\hline $\mathrm{C}_{17: 1} \omega 6 c$ & 7.2 & 2.7 & - & 5.3 \\
\hline iso- $\mathrm{C}_{17: 0}$ & 4.7 & 8.8 & 5.2 & 2.8 \\
\hline iso- $\mathrm{C}_{17: 1} \omega 9 c$ & 16.2 & 19.3 & 16.8 & 15.3 \\
\hline anteiso- $\mathrm{C}_{17: 0}$ & - & 0.7 & - & - \\
\hline $\mathrm{C}_{18: 0}$ & 1.0 & 1.0 & 1.1 & - \\
\hline $\mathrm{C}_{18: 1} \omega 7 c$ & - & - & 0.7 & - \\
\hline iso- $\mathrm{C}_{18: 0}$ & 0.6 & 0.5 & - & 0.5 \\
\hline Summed feature $3^{*}$ & 3.8 & 6.5 & 8.8 & 5.7 \\
\hline Unknown ECL 11.799 & 6.4 & 2.8 & 2.8 & 2.7 \\
\hline
\end{tabular}

${ }^{*}$ Summed feature 3 contains iso- $\mathrm{C}_{15: 0} 2-\mathrm{OH}$ and/or $\mathrm{C}_{16: 1} \omega 7 c$.

addition, the two strains could be differentiated from other members of the genus Rhodanobacter on the basis of phenotypic properties, fatty acid compositions and DNA $\mathrm{G}+\mathrm{C}$ contents (Tables 1 and 2).
On the basis of the data presented here, strains GR17- $7^{\mathrm{T}}$ and GP18-1 ${ }^{\mathrm{T}}$ represent two novel species of Rhodanobacter, for which we propose the names Rhodanobacter ginsengisoli sp. nov. and Rhodanobacter terrae sp. nov.

\section{Description of Rhodanobacter ginsengisoli sp. nov.}

Rhodanobacter ginsengisoli (gin.sen'gi.so'li. N.L. n. ginsengum ginseng; L. n. solum soil; N.L. gen. n. ginsengisoli of soil from a ginseng field, the source of the type strain).

Cells are Gram-negative, motile, aerobic rods (0.5$0.6 \times 2.0-3.5 \mu \mathrm{m})$. Temperature range for growth is 5$35{ }^{\circ} \mathrm{C}$; no growth occurs at $40{ }^{\circ} \mathrm{C}$. Optimum temperature for growth is $28{ }^{\circ} \mathrm{C}$. Grows at $\mathrm{pH}$ 5.0-9.0. Tolerates up to $3 \% \mathrm{NaCl}$, but not $5 \% \mathrm{NaCl}$. Colonies on R2A medium are yellow, circular and slightly convex with clear margins. Positive for catalase and oxidase. Negative for nitrate reduction, glucose fermentation, indole production, arginine dihydrolase, urease and $\beta$-galactosidase. Hydrolyses aesculin, casein, gelatin, Tween 80 and tyrosine, but not chitin, carboxymethylcellulose, DNA, pectin or starch. Major fatty acids are iso- $\mathrm{C}_{17: 1} \omega 9 c$, iso- $\mathrm{C}_{16: 0}$ and iso- $\mathrm{C}_{11: 0}$ $3-\mathrm{OH}$. The DNA $\mathrm{G}+\mathrm{C}$ content of the type strain is $61.0 \mathrm{~mol} \%$.

The type strain, GR $17-7^{\mathrm{T}}\left(=\right.$ KACC $11762^{\mathrm{T}}=$ DSM $\left.18993^{\mathrm{T}}\right)$, was isolated from a soil sample from a ginseng field in Yeongju province, South Korea.

\section{Description of Rhodanobacter terrae sp. nov.}

Rhodanobacter terrae (ter'rae. L. gen. n. terrae of the earth).

Cells are Gram-negative, non-motile, aerobic rods $(0.5 \times 2.0-5.0 \mu \mathrm{m})$. Temperature range for growth is 5 $30{ }^{\circ} \mathrm{C}$; no growth occurs at $35{ }^{\circ} \mathrm{C}$. Optimum temperature for growth is $25-28{ }^{\circ} \mathrm{C}$. Grows at $\mathrm{pH} 4.0-8.0$. Tolerates up to $2 \% \mathrm{NaCl}$, but not $3 \% \mathrm{NaCl}$. Colonies on R2A medium are yellow, circular and slightly convex with clear margins. Positive for catalase, oxidase and $\beta$-galactosidase. Negative

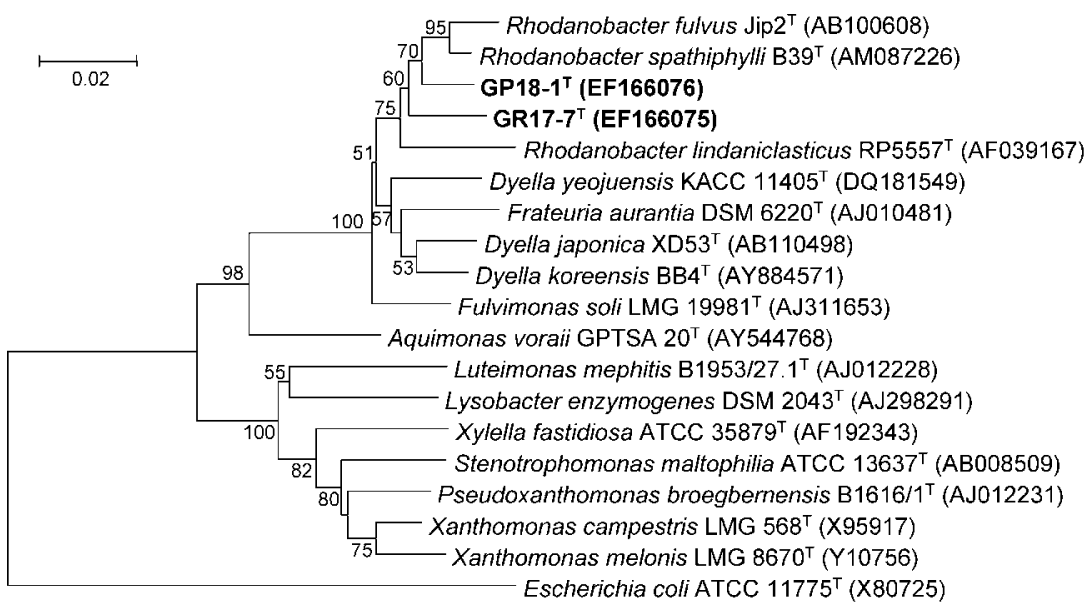

Fig. 1. Phylogenetic dendrogram constructed from a comparative analysis of 16S rRNA gene sequences showing the relationships between strains GR17-7 ${ }^{\top}$, GP $18-1^{\top}$ and related species. Escherichia coli ATCC $11775^{\top}$ was used as an outgroup. Bootstrap values (expressed as percentages of 1000 replications) greater than $50 \%$ are shown at branch points. Bar, 2 substitutions per 100 nucleotide positions. 
for nitrate reduction, glucose fermentation, indole production, arginine dihydrolase and urease. Hydrolyses aesculin, Tween 80 and tyrosine, but not casein, chitin, carboxymethylcellulose, DNA, gelatin, pectin or starch. Major fatty acids are iso- $\mathrm{C}_{17: 1} \omega 9 c$, iso- $\mathrm{C}_{16: 0}$ and iso- $\mathrm{C}_{15: 0}$. The DNA G $+\mathrm{C}$ content of the type strain is $62.5 \mathrm{~mol} \%$.

The type strain, GP18-1 ${ }^{\mathrm{T}}\left(=\right.$ KACC $11761^{\mathrm{T}}=$ DSM $\left.19241^{\mathrm{T}}\right)$, was isolated from a soil sample from a ginseng field in Ansung province, South Korea.

\section{Acknowledgements}

This study was supported by the National Institute of Agricultural Biotechnology (NIAB grant no. 06-4-11-19-1), Rural Development Administration, Republic of Korea.

\section{References}

De Clercq, D., Van Trappen, S., Cleenwerck, l., Ceustermans, A., Swings, J., Coosemans, J. \& Ryckeboer, J. (2006). Rhodanobacter spathiphylli sp. nov., a gammaproteobacterium isolated from the roots of Spathiphyllum plants grown in a compost-amended potting mix. Int J Syst Evol Microbiol 56, 1755-1759.

Hiraishi, A. (1992). Direct automated sequencing of $16 \mathrm{~S}$ rDNA amplified by polymerase chain reaction from bacterial cultures without DNA purification. Lett Appl Microbiol 15, 210-213.
Im, W. T., Lee, S. T. \& Yokota, A. (2004). Rhodanobacter fulvus sp. nov., a $\beta$-galactosidase-producing gammaproteobacterium. $J$ Gen Appl Microbiol 50, 143-147.

Kumar, S., Tamura, K. \& Nei, M. (2004). MEGA3: integrated software for Molecular Evolutionary Genetics Analysis and sequence alignment. Brief Bioinform 5, 150-163.

Mesbah, M., Premachandran, U. \& Whitman, W. B. (1989). Precise measurement of the $\mathrm{G}+\mathrm{C}$ content of deoxyribonucleic acid by high-performance liquid chromatography. Int J Syst Bacteriol 39, 159-167.

Nalin, R., Simonet, P., Vogel, T. M. \& Normand, P. (1999). Rhodanobacter lindaniclasticus gen. nov., sp. nov., a lindane-degrading bacterium. Int J Syst Bacteriol 49, 19-23.

Seldin, L. \& Dubnau, D. (1985). Deoxyribonucleic acid homology among Bacillus polymyxa, Bacillus macerans, Bacillus azotofixans, and other nitrogen-fixing Bacillus strains. Int J Syst Bacteriol 35, 151-154.

Smibert, R. M. \& Krieg, N. R. (1994). Phenotypic characterization. In Methods for General and Molecular Bacteriology, pp. 607-654. Edited by P. Gerhardt, R. G. E. Murray, W. A. Wood \& N. R. Krieg. Washington, DC: American Society for Microbiology.

Thompson, J. D., Higgins, D. G. \& Gibson, T. J. (1994). CluSTAL W: improving the sensitivity of progressive multiple sequence alignment through sequence weighting, position-specific gap penalties and weight matrix choice. Nucleic Acids Res 22, 4673-4680.

Weisburg, W. G., Barns, S. M., Pelletier, D. A. \& Lane, D. J. (1991). $16 \mathrm{~S}$ ribosomal DNA amplification for phylogenetic study. J Bacteriol 173, 697-703. 